\title{
Influence of Heating Rate and Temperature on the Yield and Properties of Pyrolysis Oil Obtained from Waste Plastic Bag
}

\author{
M. Sigit Cahyono', Ucik Ika Fenti Styana² \\ ${ }^{1}$ Universitas Proklamasi 45 Yogyakarta \\ 2Institut Teknologi Yogyakarta \\ Email: sigitup45@gmail.com
}

\begin{abstract}
The objective of the research was to investigate the influence of heating rate and temperature in the reactor on the yield and properties of pyrolysis oil obtained from waste plastic bag, that is considered as lowdensity polyethylene (LDPE). The experiments were performed in fixed bed reactor equipped with a steam atomizing burner, a temperature controller, and a condenser. Approximately, the amount of ten kilograms of waste plastic bag loaded into the reactor chamber and then pyrolyzed using the temperature between 250 and $450^{\circ} \mathrm{C}$ and heating rates of 5 to $15^{\circ} \mathrm{C} / \mathrm{min}$. The results showed that as the oil yield decreased, the heating rate increased. Alternatively, the oil yield increased with temperature and the wax content decreases as the temperature increases. The highest quantity of pyrolysis oil was produced from waste plasctic bag is $45 \%$, in the temperature $450^{\circ} \mathrm{C}$ and the heating rate $15^{\circ} \mathrm{C} / \mathrm{min}$, with wax content of $25 \%$, solid char of $12 \%$ and non-condensable gas of $41 \%$. The physical properties of oil were evaluated and compared to those of diesel oil. The analysis results showed that the oil product's properties from pyrolysis of the waste plastic bag in temperature $450^{\circ} \mathrm{C}$, were relatively closer to those of diesel oil with caloric value $11,043 \mathrm{kcal} / \mathrm{kg}$, specific gravity of 0.812 , kinematic viscosity $2.80 \mathrm{~mm}^{2} / \mathrm{s}$, and flash point of $27^{\circ} \mathrm{C}$.
\end{abstract}

Keywords : Pyrolysis, heating rate, temperature, yield, waste plastic bag

\section{Introduction}

The production of waste in Indonesia has become a major focus in recent years. The considerable growth of the population caused a great amount of wastes. Plastics as one of the wastes, has been used in many fields and it has already become a part of modern life nowadays, especially for the plastic bags made from polyethylene (PE).

The standard plastic bags with thin polyethylene sheets is produced commercially from polymerization of ethylene (PE). PE is divided into categories based on the density and the molecular branching frequency. The 
top two types of most important plastic bags production are high-density PE (HDPE) and low-density PE (LDPE). HDPE is a copolymer with the amount up to $1 \%$ of 1-butene and is made along with either $\mathrm{Cr}$ or Zieglercatalysts and the temperatures as low as $60{ }^{\circ} \mathrm{C}$. More recently, single site catalysts such as metallocenes have also been used. LDPE is produced at high temperatures (200-300 ${ }^{\circ} \mathrm{C}$ ) and supercritical ethylene pressures (130-260 MPa) using peroxide-free radical initiators. HDPE is a linear copolymer with a density range of $0.945-0.965 \mathrm{~g} / \mathrm{cm}^{3}$, LDPE is branched with densities ranging from 0.915 to $0.925 \mathrm{~g} / \mathrm{cm}^{3}$ [1].

The use of plastic bags-not biodegradable-causes a significant increase of plastic waste. The recycling of plastic waste is not easy to be obtained, because it can be found with the significant quantities in landfills and also in the street causing the adverse impacts on health and strong environmental damage [2]. Thus, the recycling process and recovery efforts need to be done to avoid the pollution and reduce the damages caused by waste plastic bags.

One of the chemical recycling techniques for the plastic materials is pyrolysis, which recently increases public interest as an acceptable choice of waste material treatment from both environmental and economical aspects [3]. Pyrolysis is the process of thermally degrading long chain polymer molecules into smaller, less complex molecules through heat and pressure management. The process requires intense heat with shorter duration in absence of oxygen. The three major products that are produced during pyrolysis; oil, gas and char which are valuable for the industries especially for production and refineries sector [4] [5] [6]. The Process will be completed in four steps, including initiation, transfer, decomposition and termination [7].

\begin{tabular}{|c|c|c|c|c|c|c|c|}
\hline & Units & ASTM D975 b & EN 590 & PPEH-L & PPEH-H & $1: 1 \mathrm{~L} / \mathrm{H}$ & ULSD \\
\hline Low temperature & ${ }^{\circ} \mathrm{C}$ & & & & & & \\
\hline $\mathrm{CP}$ & & $-^{c}$ & $-^{c}$ & $-30.1(0.1)$ & $4.7(0.2)$ & $-5.9(0.2)$ & $-17.5(0.3)$ \\
\hline PP & & $-^{c}$ & $-^{c}$ & $-37.3(0.6)$ & $4.0(0)$ & $-8.3(1.2)$ & $-20.3(0.6)$ \\
\hline CFPP & & $-^{c}$ & $-^{c}$ & $-31.0(0)$ & $3.7(0.6)$ & $-6.0(0)$ & $-16.0(0)$ \\
\hline \multicolumn{8}{|l|}{ Oxidative stability: } \\
\hline $\mathrm{IP}, 110^{\circ} \mathrm{C}$ & $\mathrm{h}$ & $-^{c}$ & $\geq 20$ & $3.9(0.3) / 14.4(0.8)^{\mathrm{d}}$ & $12.9(1.5) / 24^{d}$ & $7.7(09) />24^{d}$ & $>24$ \\
\hline OT & ${ }^{\circ} \mathrm{C}$ & $-^{c}$ & $-c$ & $175.2(0.3) / 186.9(0.4)^{\mathrm{d}}$ & $190.1(0.7) / 202.1(0.5)^{d}$ & $180.8(0.5) / 192.7(0.6)^{d}$ & $196.2(0.5)$ \\
\hline $\mathrm{KV}, 40^{\circ} \mathrm{C}$ & $\mathrm{mm}^{2} / \mathrm{s}$ & $1.9-4.1$ & $2.0-4.5$ & $1.20(0.01)$ & $2.96(0)$ & $2.08(0)$ & $2.28(0.01)$ \\
\hline $\mathrm{DCN}$ & & $\geq 40$ & $\geq 51$ & $54.6(1.1)$ & $73.4(1.4)$ & $66.3(1.5)$ & $47.4(0.9)$ \\
\hline Flash point & ${ }^{\circ} \mathrm{C}$ & $\geq 52$ & $\geq 55$ & $<30$ & $81.5(0.7)$ & $90.3(1.8)$ & $65.0(0.7)$ \\
\hline Wear scar, $60{ }^{\circ} \mathrm{C}$ & $\mu \mathrm{m}$ & $\leq 520$ & $\leq 460$ & $293(3)$ & $198(10)$ & $282(3)$ & $581(5)$ \\
\hline Sulfur & $\mathrm{ppm}$ & $\leq 15$ & $\leq 10$ & 3 & 2 & 2 & 8 \\
\hline $\mathrm{SG}, 15^{\circ} \mathrm{C}$ & & $-c$ & $-{ }^{c}$ & $0.777(0.001)$ & $0.803(0.001)$ & $0.792(0.001)$ & $0.841(0.001)$ \\
\hline Density, $15^{\circ} \mathrm{C}$ & $\mathrm{kg} / \mathrm{m}^{3}$ & $-^{c}$ & $820-845$ & $776(1)$ & $802(0)$ & $791(1)$ & $840(1)$ \\
\hline $\mathrm{ST}, 40^{\circ} \mathrm{C}$ & $\mathrm{mN} / \mathrm{m}$ & $-^{c}$ & $--^{c}$ & $22.5(0.1)$ & $24.7(0.1)$ & $23.6(0.2)$ & $25.1(0.2)$ \\
\hline Moisture & $\mathrm{ppm}$ & $-^{c}$ & $\leq 200$ & $106(2)$ & $64(3)$ & $84(1)$ & $49(3)$ \\
\hline HHV & $\mathrm{M} / \mathrm{kg}$ & $-^{c}$ & $-^{c}$ & $45.86(0.22)$ & $46.16(0.09)$ & $46.04(0.08)$ & $45.15(0.19)$ \\
\hline
\end{tabular}

Table 1. Fuel Properties of pyrolyzed polyethylene Hydrocarbons

Comparison of pyrolysed polyethylene hydrocarbons (PPEH) oil with conventional petroleum-derived ultra-low sulfur (b15 ppm S) diesel fuel (ULSD) is shown in Table 1 [8]. 
There are numerous published research papers based on the potential of various types of plastics for the pyrolysis process in liquid production. It should be noted that the results and quality of the product are highly dependent on the parameter setting. The main parameters are temperature, reactor type, residence time, pressure, different catalysts usage and type of fluidizing gas with its flow rate [4]. Furthermore, the TGA experiment showed that the heating rate has an important role on the decomposition reaction; when the heating rate increases, the decomposition temperature of the plastics samples also increases [9]. Thus, the aims of this paper is to study the influence of heating rate and temperature on the yield and properties of pyrolysis oil obtained from waste plastic bag, which are immensely available in Indonesia.

\section{Materials and Methods}

\subsection{Materials}

The plastics used in this research were waste plastic bags from Low Density Polyethylene material. First step, the plastic is washed until it dried up and then be prepared into small pieces. Ten (10) $\mathrm{kg}$ of the plastic pieces the be placed into the reactor for each pyrolisis process.

\subsection{Methods}

The experiment was performed in a cylindrical reactor with conical top cover, made from steel with the dimension of $0.7 \mathrm{~m}$ in diameter and $1.5 \mathrm{~m}$ in high with a $\mathrm{K}$ type thermocouples were placed in the top of reactor. The furnace was covered with firebrick as heat isolator. The condensers were made from carbon steel tube with diameter of 4 inch. The length of first condenser is $1 \mathrm{~m}$ and second condenser is $1.5 \mathrm{~m}$ length. There were ten vapor tubes with diameter $1 / 2$ inch placed inside each condenser. The pump with 0.5 $\mathrm{kW}$ power, was used to flow the cooling water from receiver to condenser. The pyrolysis batch reactor used in this study was shown in Figure 1.

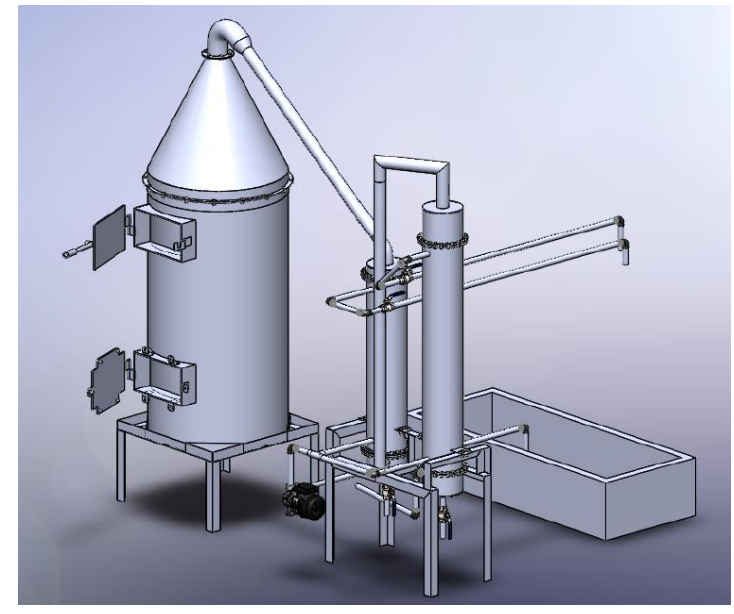

Figure 1. Pyrolysis Batch Reactor 
The experiments were obtained in two parts; first, to investigate the effect of the heating rate on the pyrolysis product yields, for this purpose, plastic bags were pyrolysed at heating rates 5,10 , and $15^{\circ} \mathrm{C} / \mathrm{min}$. The reactor was heated from the room temperature to a final temperature of $450{ }^{\circ} \mathrm{C}$ (held $15 \mathrm{~min}$ ). The second part was performed to establish the effect of pyrolysis temperature on the pyrolysis yields. The reactor was heated from room temperature to desired temperature $\left(250,350\right.$, and $450^{\circ} \mathrm{C}$, held for $\left.15 \mathrm{~min}\right)$ at heating rate of $15^{\circ} \mathrm{C} / \mathrm{min}$.

The reactor was heated till reach the ideal temperature using a hot flue gas from combustion of pyrolysis oil by steam atomizing burner. The organic vapors produced within the heating chamber at high temperature and then was condensed into liquid oil in the condenser. Water circulating cooler was used to decrease the temperature of condenser for the maximum condensation of organic vapors into liquid oil in the condenser. The condensed organic vapors (liquid oil) were collected from the oil collector assembly at the bottom of the condenser, while the uncondensed products (gases) from the same liquid oil pipe were exhausted outside, and solid char were taken from the bottom of reactor.

\section{Result and Discussion}

\subsection{Influence of Heating rate}

Table 2 showed the yield of conversion degree oil, char and gases (Gas yield estimated $=100$-char-liquid) from the pyrolysis of the waste plastic bag in relation to the heating rate from 5 to $15{ }^{\circ} \mathrm{C} / \mathrm{min}$ to a final pyrolysis temperature of $450{ }^{\circ} \mathrm{C}$ in the fixed bed reactor.

\begin{tabular}{llccc}
\hline \multirow{2}{*}{ No } & \multirow{2}{*}{ Product } & \multicolumn{3}{c}{ Heating rate ( $\mathbf{0}$ C/min) } \\
\cline { 3 - 5 } & & 5 & 10 & 15 \\
\hline 1 & Liquid & 53.1 & 51.3 & 47 \\
2 & Char & 14.5 & 11.4 & 12 \\
3 & Gases & 32.4 & 37.3 & 41 \\
& & & & \\
\hline
\end{tabular}

Table 2. Yield of Pyrolysis Product (weight \%) at various heating rate

The process of plastic pyrolysis can be obtained as the heating rate increases, the conversion degree and the yield of gases increased, while the yields of oil and char decreased, respectively. These results shows same tendency as obtained in the pyrolysis of plastics [10]. Williams and Ahmad [11] suggest that the pyrolysis process may be processed by a diffusion-limited process controlled by heat and product diffusion. They suggest that the extent 
of diffusion control increases at high heating rates because products are generated faster than it can diffuse out of the pores, consequently secondary coking reactions will occur.

\subsection{Influence of Temperature}

Second part of the experiments, it was performed in the reactor with pyrolysis temperature between 250 and $450{ }^{\circ} \mathrm{C}$ at the heating rate of $15^{\circ} \mathrm{C} / \mathrm{min}$, resulted the product yields of pyrolysis of the waste plastic bag in relation to the temperature as shown in the table 3.

\begin{tabular}{cccccc}
\hline No & Temperature & $\begin{array}{c}\text { Pyrolysis } \\
\text { Oil }\end{array}$ & Wax & $\begin{array}{c}\text { Noncondensable } \\
\text { gas }\end{array}$ & $\begin{array}{c}\text { Solid } \\
\text { Residue }\end{array}$ \\
\hline 1 & $250^{\circ} \mathrm{C}$ & 8 & 52 & 5 & 35 \\
2 & $350^{\circ} \mathrm{C}$ & 15 & 27 & 35 & 23 \\
3 & $450^{\circ} \mathrm{C}$ & 45 & 2 & 41 & 12 \\
\hline
\end{tabular}

Table 3. Effect of temperature on th eyield of pyrolysis products (weight \%)

At the lowest pyrolysis temperature of $250{ }^{\circ} \mathrm{C}$, the pyrolysis oil yield was low, which reflects the incomplete pyrolysis process form as a large amount of wax. As the temperature was increased, the pyrolysis oil yield was also increased until it reached the maximum temperature at $450^{\circ} \mathrm{C}$. Therefore, there was a progressive increasing in gas yield and conversion degree from $250^{\circ} \mathrm{C}$ to $450^{\circ} \mathrm{C}$, while the amount of char and wax has decreased.

These results showed the same tendency from pyrolysis of plastics [12] [13] [14]. So it can be concluded that temperature has an important role in the of products distribution. As material reached the elevated temperatures, the different chemical components experienced the thermal degradation affecting the conversion of yield and the product quality. The increasing of the pyrolysis temperature caused a significant increase in the pyrolysis oil and gas yields. This result was attributed to the gas phase cracking reactions to yield increased hydrocarbons. At low temperatures (below $250^{\circ} \mathrm{C}$ ) the pyrolysis of oil yields are reduced because of the coking reactions of the pyrolysis oil through the conversion of the pyrolysis oil to solid product and/or incomplete pyrolysis form of waxes. Consequently, an optimum temperature which is maximum temperature of oil yields are obtained.

Furthermore, the characteristics of all liquid products (mixed of pyrolysis oil and waxes) have been evaluated, the analysis results of this examination are presented in Table 4. 


\begin{tabular}{llcccc}
\hline \multirow{2}{*}{ No } & \multicolumn{1}{c}{ Parameters } & \multicolumn{3}{c}{ Temperature $\left({ }^{\circ} \mathrm{C}\right)$} & Diesel \\
\cline { 3 - 5 } & & 250 & 350 & 450 & Oil [12] \\
\hline 1 & Caloric Value $(\mathrm{kcal} / \mathrm{kg})$ & 6,258 & 10,957 & 11,043 & 11,281 \\
2 & Flash Point $\left({ }^{0} \mathrm{C}\right)$ & 96 & 55 & 27 & 55 \\
& Viscosity Kinematic at $40^{\circ} \mathrm{C}$ & 12.10 & 5.42 & 2.80 & 2.1 \\
3 & $\left(\mathrm{~mm}^{2} / \mathrm{s}\right)$ & 1.0492 & 0.8601 & 0.8102 & 0.82 \\
4 & Spesific Gravity & & & & \\
\hline
\end{tabular}

Table 4. Properties of the liquid products in comparison with diesel oil

Table 4 showed that the liquid produced from pyrolysis process in temperature $450^{\circ} \mathrm{C}$ has higher gross heating value, and lower flash point. The result has more specific Gravity and Viscosity Kinematic than liquid that produced from pyrolysis process in other temperature. Since the increasing of temperature facilitated secondary of cracking reactions, it can be assumed that the liquid recovered had lighter hydrocarbon fraction (lower molecular weight hydrocarbon). In general, lighter hydrocarbon fraction in a homologous series had a lower boiling point, a higher heating value, and lower viscosity [15].

According to Table 4, it was indicated that among other processes, the liquid product taken from $450^{\circ} \mathrm{C}$ of pyrolysis had the physical properties closer to diesel oil. If compared to it, the liquid was lighter and easier to burn and slightly more viscous. In addition, the liquid had similar quality of energy content with diesel oil. Although many similarities have been found in the liquid product (especially from pyrolysis process in $450^{\circ} \mathrm{C}$ ) and diesel oil. With the record, more comprehensive analyses should be done if the oil were to be used as a diesel oil substitute. Other oil properties, such as the smoke point, sulfur content, copper strip corrosion, and odor, should be evaluated and meet the standard criteria for commercial diesel oil [14].

\section{Conclussion}

Pyrolysis of waste plastic bag to produce oil increases along with the increasing of temperature. Highest pyrolysis oil yield is $47 \%$ (weight) was obtained from $450^{\circ} \mathrm{C}$ and heating rate $15^{\circ} \mathrm{C} / \mathrm{min}$. The pyrolysis oil formation is also affected by the heating rate. As the heating rate increases, the conversion degree and the yield of gases increased and the yields of liquid and char decreased. The physical properties of the liquid production compared favorably with diesel oil, which shows that it can be used as diesel oil substitution. However, a more detailed analysis should be conducted to assure further utilization of the liquid. Hence pyrolysis of these waste plastic bags does not only manage the environment but is also a means of cheaper energy source for the alternative fuel. 


\section{References}

[1] H. Wittcoff, B.G.Reuben and J. Plotkin, Industrial Organic Chemicals, 2nd ed., Hoboken: Wiley-Interscience, 2004.

[2] S. Ouminga, T. Rogaume, T. Daho, F. Richard and J. Koulidiati, "Thermal Degradation of Polythylene Bags and Millet Stalks: Influence of the Temperature and the Local Concentration of Oxygen on the Conversion Rate of Carbon," Advances in Chemical Engineering and Science, vol. 2, pp. 155-165, 2012.

[3] S. Papuga, P. Gvero and L. Vukic, "Temperature and Time Influence on the Waste Plastics Pyrolisis in the Fixed Bed Reactor," Thermal Science, vol. 20, no. 2, pp. 731-741, 2016.

[4] S. Sharuddin, F. Abnisa, W. M. A. W. Daud and M. K. Aroua, "A Review on Pyrolysis of Plastic Wastes," Energy Conversion and Management, vol. 115, p. 308-326, 2016.

[5] H. B. Sukarjo, M. S. Cahyono and Wardoyo, "Influence of Temperature to Bio-Oil Yiel d from Organic Waste Pyrolysis Process," in Seminar Nasional Aplikasi Sains \& Teknologi (SNAST), 2014.

[6] M. S. Cahyono, "Influence of Raw Material to Organic Waste Pyrolysis Process as Reneable Energy Source," Journal of Sciences and Environmental Technology, vol. 5, no. 2, pp. 67-76, 2013.

[7] T. Faravelli, M. Pinciroli, F. Pisano, G. Bozzano, M. Dente and E. Ranzi, "Thermaldegradation of polystyrene," Journal of Analytical and Applied Pyrolysis, vol. 60, pp. 103-121, 2001.

[8] B. K. Sharma, B. R. Moser, K. E. Vermillion, K. M. Doll and N. Rajagopalan, "Production, Characterization and Fuel Properties of Alternative Diesel Fuel from Pyrolysis of Waste Plastic Grocery Bags," Fuel Processing Technology, vol. 122, pp. 79-90, 2014.

[9] I. Kayacan and O. M. Dogan, "Pyrolysis of Low and High Density Polyethylene," Part I: Non-isothermal Pyrolysis Kinetics, Energy Sources, vol. 30, pp. 385-391, 2008.

[10] A. Aboulkas, T. Makayssi, L. Bilali, K. E. harfi, M. Nadifiyine and M. Benchanaa, "Co-pyrolysis of Oil Shale and Plastics: Influence of Pyrolysis Parameters on the Product Yields," Fuel Processing Technology, vol. 96, pp. 209-213, 2012.

[11] P. Williams, T. and N. Ahmad, "Influence of process conditions on the pyrolysis Pakistanioil shales," Fuel, vol. 78, pp. 653-662, 1999.

[12] F. Mabood, J. Shah, M. R. Jan, Z. Hussain and F. Jabeen, "Catalytic Conversion of Waste Low Density Polyethylene into Valuable Products," $J$. Chem. Soc. Pak, vol. 32, no. 5, 2010.

[13] T. Ademiluyi and C. Akpan, "Preliminary Evaluation of Fuel Oil Produced From Pyrolysis of Low Density Polyethylene Water-Sachet Wastes," 
Journal of Applied Sciences and Environmental Management, vol. 11, no. 3, pp. 15-19, 2007.

[14] W. W. Mandala, M. S. Cahyono, S. Maarif, H. B. Sukarjo and Wardoyo, "Influence of Temperature to Yield and Caloric Value of Plastic Waste Pyrolysis Oil," Journal of Mechanical and Thermal System, vol. 1, no. 2, 2016.

[15] A. T. Yuliansyah, A. Prasetya, M. A. A. Ramadhan and R. Laksono, "Pyrolysis of Plastic Waste to Produce Pyrolytic Oil as An Alternative Fuel," International Journal of Technology, vol. 7, pp. 1076-1083, 2015. 